\title{
Developing Nonword Spelling Assessment for Elementary Students
}

\author{
Bobae Kim, Minwha Yang \\ Department of Education, Kookmin University, Seoul, Korea
}

\author{
Correspondence: Minwha Yang, $\mathrm{PhD}$ \\ Department of Education, Kookmin University, \\ 77 Jeongneung-ro, Seongbuk-gu, Seoul 02707, \\ Korea \\ Tel: +82-2-943-0791 \\ Fax: +82-2-973-0770 \\ E-mail: myang@kookmin.ac.kr
}

Received: April 5, 2017

Revised: May 31, 2017

Accepted: June 5, 2017

This article is based on the master's thesis of the first author.

This work was supported by the Technology Innovation Program (or Industrial Strategic Technology Development Program(10065156, Developing intervention games to improve Cognitive Processing Ability(CPA) of people with Korean dyslexia) funded By the Ministry of Trade, Industry \& Energy(MOTIE, Korea).

\begin{abstract}
Objectives: The current study was designed to develop a diagnostic instrument to test children's developmental level of phonetic spelling ability, which can also be used to identify students with spelling disabilities. Methods: The Korean Developmental Spelling Assessment-Nonword (KDSA-NW) was developed based on a review of previous research and three pilot studies. Items of KDSA-NW were constructed with seven spelling features: principal vowels, initial consonants, final consonants, aspirated consonants, tense consonants, Y glides, and W glides. The 30 finalized items of KDSA-NW were two syllable nonwords of CVC-CVC. KDSA-NW was standardized across 779 students in grades 1-3 and its reliability and validity of KDSA-NW were estimated. Results: The Cronbach's alpha coefficient and split-half correlation revealed that KDSA-NW was a highly reliable measure. The content validity scores were satisfactory, proving the items were appropriate to test the phonetic spelling ability of elementary students. The normed chi-square, RMSEA, and SRMR results of principal component analysis demonstrated that the construction of KDSA-NW was solid. The high correlation between the KDSA-NW score and the KDSA phonological spelling feature test revealed that the concurrent validity of KDSA-NW was appropriate. Conclusion: The results of the study showed that KDSA-NW is a reliable and valid assessment to test the phonetic spelling ability of students in grades 1-3.
\end{abstract}

Keywords: Spelling assessment, Spelling development, Assessment development, Nonword, Phonological development 철자는(spelling) 정서법(handwriting), 작문(written expressioncomposition)과 함께 쓰기능력을 구성하는 요소로(Lerner, 2000), 자음과 모음을 맞추어 음절 단위의 글자를 만드는 것을 일컫는다. 철자는 학생들이 초등학교 교육을 통해 반드시 습득해야 하는 기 초학습능력일 뿐 아니라 작문을 위한 기본능력이다. 우리나라 학 교교육에서도 초등학교 저학년의 교육과정에서 철자교육을 중요 하게 다루고 있는데, 거의 모든 초등학교에서 1,2 학년 아동들에게 매주 받아쓰기 시험을 실시하고 그 결과를 통해 철자능력의 향상 을 평가하고 있다.

그러나 이러한 노력에도 불구하고 현장교사들은 초등학교 1,2 학년에 읽기부진아동(23\%)보다 쓰기부진아동(55\%)이 많다고 인 식하고 있었다(Lee \& Jeon, 2007). 실제 철자학습장애가 학령기의 $10 \%$ 를 넘는다고 보고될 만큼 철자 문제를 심각하게 경험하고 있는
학생의 수는 간과할 수 없는수준에 이르고 있다(Kim \& Kim, 2013). 학령기 철자에 대한 어려움은 청소년기와 성인기까지 지속되며 (Bruck, 1993; Deacon, Parrila, \& Kirby, 2006), 철자능력은 향후 작 문능력을 예측하는 중요한 변인으로 알려져 있어 철자의 중요성은 상당하다고 할 수 있다(Graham, Berninger, Abbott, Abbott, \& Whitaker, 1997). 따라서 기초학습영역인 철자에 대한 아동의 문제 를 조기에 정확히 진단하여 필요한 부분을 체계적으로 교수할 수 있도록 이에 적절한 지원이 필요하다. 본 연구를 통해 연구자들은 아동의 초기 철자발달 능력인 음운적 철자능력을 정확히 진단할 수 있는 표준화된 검사이면서도, 검사 결과를 교수하는 데에 쉽게 활용할 수 있도록 철자 유형별로 교수 목표를 제시할 수 있는 철자 검사도구를 개발하고자 하였다.

본 연구에서 개발하고자 하는 철자 검사도구는 한글 철자발달 
이론과 인지과정이론인 이중경로이론을 토대로 설계되었다. 선행 연구들에 따르면(Yang, 2009, 2014) 한글 철자의 발달과정은 크게 음운적 철자단계와 형태론적 철자단계로 나누어 볼 수 있다. 먼저, 아동들은 소리에 해당하는 자소를 대응시켜 소리 나는 대로 철자 하는 음운유형 철자발달 단계를 거친다. 음운유형의 철자는 대부 분 유치원시기에서 초등학교 1학년 사이에 숙달수준에 도달하며, 이 시기에 숙달수준으로 발달하는 음운유형에는 기본모음, 기본 초성, 기본종성 등의 철자유형이 포함된다. 학교에 입학한 후에는 거센소리초성, 된소리초성, $\mathrm{y}$ 계열모음, $\mathrm{w}$ 계열모음들이 빠르게 습 득된다.

음운론적 철자단계가 어느 정도 숙달수준에 이르면 소리가 일대 일로 대응되지 않아도 형태소를 지켜 쓰는 법을 배우는 형태론적 철자단계에 본격적으로 진입한다(Yang, 2014). 이때 학습되는 형태 소유형에는 음운변동, 겹받침 등 형태소 지식이 있어야 하는 철자 유형들이 포함되며 형태론적 철자발달은 초등학교 고학년까지 이 어지는 것으로 보고 있다(Yang, 2009, 2014). 본 연구에서 개발한 검사도구는 이 중에서도 초등학교 입학 초기에 대부분의 아동들 이 숙달수준에 도달하는 음운적 철자에 대한 능력을 정확히 측정 하도록 구성되었다. 현재 음운적 철자능력을 측정하는 표준화된 검사도구로 한글 철자 발달검사(Korean Developmental Spelling Assessment, KDSA; Yang, Ra, Lee, \& Kim, 2016)의 음운유형 철자 검사지가 있다. 그러나음운적 철자능력을 정확히 측정하기 위해서 는 실제 존재하는 단어가 아닌 무의미단어로 철자하도록 하는 과 제가 필요한데 그 이유는 이중경로이론으로 설명할 수 있다.

철자를 수행하는 중에 일어나는 인지과정을 설명하는 이론으로 '이중경로이론'이 가장 널리 받아들여지고 있다(Ellis, 1982; Newcombe \& Marshall, 1980). 이중경로이론에 따르면 철자자는 각기 독립적인 경로인 음운 경로 또는 비어휘적(nonlexical)경로, 그리고 어휘적(lexical) 경로를 통해 철자정보를 얻는다. 음운 경로를 통한 철자 경로는 음운적 코드(phonological code)를 철자적 표상(orthographic presentation)으로 변화시켜 철자하는 것을 말한다. 이는 구어로 입력된 음운적 정보를 작은 단위로 분석하여 각각의 단위 마다 음소-자소의 대응규칙을 적용한 후 대응되는 철자들을 조합 하여 하나의 문자열을 만드는 과정을 거친다. 음운 경로는 음운부 호에만 의존하여 단어를 처리하기 때문에 새로운 글자 또는 익숙하 지 않은 단어를 철자할 때 주로 활성화되며(Bishop \& Robson, 1989), 초기 철자학습자에게 특히 활용도가 높은 철자 경로이다(Marsh, Friedman, Welch, \& Desberg, 1980; Stage \& Wagner, 1992). 또한 음운 경로가 효율적인 경우 속도가 매우 빠르기 때문에 어휘적 경 로보다 경제적인 경로라는 주장도 있다(Henderson \& Chard, 1980;
Kang \& Simpson, 1996).

반면, 어휘적 경로를 통한 철자는 심성어휘집(mental lexicon)으 로부터 철자를 시각적으로 직접 인출하여 철자하는 과정을 의미한 다. 어휘력이 높고 시각적 기억력이 높은 경우 음운 경로뿐만 아니 라 어휘 경로를 사용하여 철자하게 된다. 즉, 단어의 언어적, 시각적 정보를 의미와 함께 기억저장소에 저장하고 단어를 쓸 때 직접적으 로 어휘집에 접근하여 철자하게 되는 것이다. 본 연구에서는 아동 이 음운 경로를 통해 철자하는 능력인 음운적 철자능력을 정확히 측정하기 위하여 어휘 경로를 통제할 수 있는 검사도구를 만들고 자 하였다. 이를 위하여 검사문항을 모두 무의미단어로 구성함으 로써 어휘 경로를 배제하고 음운 경로만을 사용하여 철자하는 능 력을 측정하고자하였다.

현재 한글 철자능력을 측정할 수 있는 표준화된 검사로는 한글 철자 발달검사(KDSA; Yang, Ra, et al., 2016)와 한국어 읽기검사 (Korean Language-based Reading Assessment, KOLRA; Pae, Kim, Yoon, \& Jahng, 2015)의 하위검사로서의 철자검사 두 가지가 출판 되어 있다. 두 검사도구 모두 실제 존재하는 단어나 문장을 쓰도록 설계되었다. 이 중 철자검사의 결과를 토대로 쉽게 교수정보를 얻 을 수 있도록 설계된 표준화된 검사도구는 KDSA이다(Yang, Ra, et al., 2016). KDSA는 초등학교 1, 2학년 아동을 대상으로 표준화되 었으며 한글 철자발달이론에 근거하여 음운적 철자능력과 형태론 적 철자능력을 측정하도록 만들어졌다. 교사들은 KDSA의 결과를 통해 철자 장애아동을 판별할 수 있으며, 세부 음운유형들 중에서 발달적으로 어느 유형을 먼저 가르쳐야 할지에 대한 정보를 얻을 수 있다. 그러나 KDSA검사의 문항들은 모두 실제 존재하는 단어 들로 구성되어 있으므로 피검사자의 어휘능력을 통제하지 못하여 음운적 철자능력을 정확히 진단하는 데 제한이 있다.

실제 존재하는 단어들로만 철자검사를 할 때 생기는 검사 타당 도의 문제는 앞서 설명한 이중경로이론을 토대로 설명할 수 있다. 검사의 문항이 실제 존재하는 단어로 구성될 경우 해당 단어를 자 주 접한 아동은 음운정보를 분석하고 부호화하는 능력이 충분치 않더라도, 심성어휘집에서 철자를 시각적으로 인출하는 어휘 경로 를 사용하여 정확히 철자할 가능성이 높다. 따라서 음운적 철자능 력, 즉 소리 나는 대로 철자할 수 있는지에 대한 검사에서는 문항이 의도했던 음운적 철자능력을 제대로 측정하기 어려운 것이다. 음 운적 철자능력이란 아동이 음운 경로를 사용하여 철자하는 능력 을 말하는 것이므로, 음운적 철자능력을 정확히 측정하기 위해서 는 무의미단어 또는 비단어로 검사를 수행한 결과가 더욱 정확한 정보를 줄 수 있다. 최근 학습에 어려움이 있는 아동에게 단어에 대 해 아동이 느끼는 친숙도가 철자 수행에 영향을 미친다는 보고들 
도 단어에 대한 친숙도 요인을 배제하도록 문항을 구성해야 할 필요 성을 말해준다(Choi, Kim, Yun, \& Sung, 2011; Yang \& Lee, 2012).

따라서 본 연구는 아동의 음운적 철자능력을 측정하는 무의미 단어 철자 검사도구를 개발하고, 그 신뢰도와 타당도를 검증하고 자 한다. 검사의 설계와 채점방법은 모두 $\mathrm{KDSA}$ 와 동일하므로, 본 연구를 통해 개발된 검사도구의 명칭은 무의미단어 한글 철자 발 달검사(Korean Developmental Spelling Assessment-Nonword, KDSA-NW)라 하였다. KDSA-NW는 철자 교육이 가장 중요시되 는 초등학교 $1,2,3$ 학년 아동을 대상으로 표준화되었으며, 검사의 결과가 철자 문제를 진단하는 것은 물론, 발달수준 및 철자 교수목 표에 대한 정보를 제공할 수 있도록 설계하였다. 연구문제는 다음 과 같다: (1) 음운적 철자능력을 효과적으로 측정할 수 있는 무의미 단어 철자 검사도구는 어떻게 구성되는가?; (2) 본 연구에서 개발한 철자 검사도구의 신뢰도는 어떠한가?; (3) 본 연구에서 개발한 철자 검사도구의 타당도는 어떠한가?

\section{연구방법}

\section{무의미단어 한글 철자 발달검사(KDSA-NW) 문항 개발}

KDSA-NW의 문항을 개발하기 위하여 한글 철자발달에 관련된 선행연구들과 철자 관련 검사들을 검토하였다. 문헌 분석을 통해 한글의 음운적 철자를 대표할 수 있는 음운유형을 선별하였으며, 그 다음으로 선별된 음운유형을 검사하기에 적절한 무의미단어를 개발하였다. 마지막으로 한정된 문항으로 모든 목표 유형에 대한 철자능력을 측정하기 위해 자소들이 문항에 포함되는 비율을 맞 추어 단어를 선정하였다.

\section{검사 목표 유형}

기본모음은 'ㅐ, ㅔㅔ, 시, 귀'를 제외한 단모음으로 정의하여 총 6개 자소가 포함되었다. 단모음에 포함된 'ㅐ, 게'는 발달적 특성이 아직 명확하게 밝혀지지 않아 제외하였으며(Yang, 2005, 2014; Yang, Ra, et al., 2016), '기, 귀'는 제한된 환경에서만 단모음으로 발음되고 그 외의 환경에서는 이중 모음으로 발음되므로 $\mathrm{w}$ 계열모음에 포함하 였다(Lee, 1996). 기본초성은 거센소리, 된소리를 제외한 예사소리 와 비음, 유음에 포함된 자소로 정의하여 총 8 개 자소가 포함되었 다. 기본종성은 표준 발음법에 따라 음절 말 위치에 실현되는 자음 으로 정의하여 총 8 개 자소가 포함되었다. 거센소리와 된소리 초성 에 포함된 자소는 각각 5 개였다. 'ㅎ은 예사소리로 분류되는지 혹 은 거센소리로 분류되는지 학자마다 그 견해를 달리하지만(Lee, 1999; Lee, 2003) 본 연구에서는 선행 문헌에 따라 ‘’을 거센소리
Table 1. Phonetic spelling features of Hangul orthography

\begin{tabular}{|c|c|}
\hline Spelling feature & Letter \\
\hline Principal vowel & 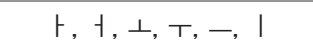 \\
\hline Initial consonant & 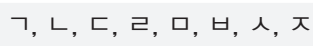 \\
\hline Final consonant & ᄀ, ᄂ, ᄃ, ᄅ, ㅁ, , ○ \\
\hline Aspirated consonant & Э, Е, ㅍ, ㅊ, ㅎ \\
\hline Tense consonant & 77, ㄸ, ㅃ, $\mu, \pi$ \\
\hline Y glide & F, $⿻$ 二, $\Perp, \pi$ \\
\hline W glide & 니, 나, 기, 꺼 \\
\hline
\end{tabular}

로 분류하였다(Lee, 2003). y계열모음은 ‘月, 케'를 제외한 y계열 이 중모음으로 정의하여 각각 4 개 자소가 포함되었다. ‘月, 켸'는 [-1]]로 발음되는 경우가 많으므로 $\mathrm{y}$ 계열모음에서 제외하였다(Bae, 2003). 또한 표준 발음법에서 자음을 첫소리로 가지고 있는 음절의 ‘ ㄱ'ㄴ는 [ I]로 발음된다는 규정에 따라' 'ㄱ'’ㅁ음은 검사 목표 유형에서 제외 하였다. $\mathrm{w}$ 계열모음은 '께, 개’를 제외한 $\mathrm{w}$-계 이중모음으로 정의하 여 각각 4 개 자소가 포함되었다. '기, 기'는 제한된 환경에서만 단모 음으로 발음되고 그 외의 환경에서는 이중 모음으로 발음되므로 $\mathrm{w}$ 계열모음에 포함하였으며(Lee, 1996), 현대 발음에는 이중모음 [기] 와 [게], [개]는 구분하기 어려워 '게, 개'를 w계열모음에서 제외하 였다(Lee, 1996). 목표 유형과 유형에 포함된 자소들에 대한 정보는 Table 1 에 제시되어 있다.

\section{예비문항 개발과 선정}

무의미단어 문항은 대부분 의미단어에서 하나 혹은 그 이상의 음소를 대치하여 만드는 방법을 사용한다(Kim, Im, \& Park, 2009; Landerl, Wimmer, \& Frith, 1997; Wurm \& Samuel, 1997). 하지만 이를 적용하여 테스트해 본 결과 아동들이 원래의 의미단어로 유 추하여 읽거나 쓰는 경우가 빈번하게 관찰되어 음운정보에 따라 쓰게 하는 문항으로 보기 어려웠다. 따라서 목표 유형의 포함 여부 에 따라 단순하고 쉬운 조합부터 복잡하고 어려운 조합까지 다양 한 조합의 단어 구조를 설정하고, 목표 유형에 포함된 자소들을 무 작위로 조합하여 예비문항 초안을 제작하였다.

다음으로 제작된 초안 문항 중 세 가지 기준을 적용하여 예비문 항을 선정하였다. 그 기준은 음운변동 규칙이 적용되지 않는 단어, 철자 검사에 타당한 단어, 현대 국어에서 의미 단어로 사용되지 않 는 무의미단어였다. 먼저 음운변동규칙이 적용되지 않는 무의미단 어를 선정하기 위해 Lee (1994)가 정리한 19 개의 음운규칙을 근거 로 1차 선별을 하였다. 무의미단어에 적용되는 음운변동규칙인 음 절말 장애음 중화, 비음화, 유음화, 격음화, 경음화, 구개음자음 뒤 에서의 구개반모음 $[y]$ 탈락 규칙이 적용되지 않는 문항들을 선정하 
였으며 문항수는 총 1,439 개였다.

그 다음으로는 1 차 선정된 1,439 개의 단어가 음운적 철자능력을 타당하게 검사할 수 있는 철자문항인지 확인하였다. 서울에 위치 한 한 대학의 난독증 및 기초학습 클리닉에 다니는 초등학교 $1,2,3$ 학년 난독증 아동을 대상으로 아동의 중재 목표에 맞게 조합 유형 별 무의미단어로 철자검사를 실시하였다. 수업이 진행됨에 따라 향 상되는 아동의 철자능력을 타당하게 검사할 수 있는지 관찰하기 위해 예비단어 중 10 개의 단어로 교육과정중심사정 $(\mathrm{CBA})$ 철자검 사를 구성하고 중재회기마다 실시하였다. 여러 실험연구를 통해 파 닉스 중재 전인 기초선 단계와 중재단계, 중재 후인 유지단계의 수 행도를 분석하여 타당도가 확보된 문항만을 선별하였다(Jung, Kim, Yang, \& Lee, 2016; Yang, Kim, \& Lee, 2016). 중재를 실시하기 전, 즉 철자 수행능력이 낮은 상태의 기초선 검사에서 난독증 아동 들이 정확하게 철자한 비율이 지나치게 높은 조합 형태는 제외하였 다. 또한 중재가 완료된 후 철자 수행능력이 향상된 상태의 유지단 계에서 아동들이 지나치게 낮은 정확도로 철자한 조합 형태는 제 외하였다. 이를 통해 최종 선정된 단어의 형태와 목표 유형들의 조 합은 Table 2에 제시되어 있다. 또한, 중재기간 동안 향상되는 진전 도 그래프의 기울기를 고려하여 향상도에 적합하지 않은 무의미단 어들을 제외하였다. 위에 제시된 조합 형태의 기준과 단어 선별 기 준에 부합하여 2 차로 선정된 단어는 514 개였다.

마지막으로 의미단어를 제외하기 위해 ‘현대 국어 사용 빈도 조 사2' (National Institute of Korean Language, 2005)를 기준으로 3 차 선별을 진행하였다. '현대 국어 사용 빈도 조사2'는 국어 교육을 위한 단계별 어휘 선정을 목적으로 진행된 기초 연구로 현대국어 를 조사하여 국어 사용 빈도를 정리한 자료이다. 현대 국어 사용 빈 도 조사보고서를 통해 본 연구로의 무의미단어로 선정된 514개의 예비문항 중 ‘공신', '선봉', ‘송진', '신공', '활복'의 5 개의 단어가 빈도 가 높지 않으나 의미단어로 사용됨이 밝혀졌다. 이들을 예비문항
에서 제외하고 총 509 개의 단어를 예비단어로 선정하였다.

문항 개발을 위한 계획 과정에서 한정된 문항으로 모든 목표 유 형에 대한 철자능력을 측정하기 위해 문항을 개발하고자 하였다. 이를 위해 선정된 509 개의 단어 중에서 문항 조합의 형태와 목표 자소가 계획된 비율에 부합하도록 균형을 맞추어 최종적으로 120 문항을 추렸다.

\section{예비검사}

본검사를 실시하기 전에 문항을 보완, 수정하기 위한 예비검사를 세 차례에 걸쳐 진행하였다. 1 차 예비검사는 예비문항 중 초등학교 $1,2,3$ 학년 수준에 적절한 난이도인 것만을 선정하기 위하여 실시되 었으며, 2 차 예비검사는 1 차 예비검사 결과 선정된 문항 중 난이도 와 변별도가 적절한 문항들을 가려내기 위하여 실시되었다. 마지막 으로 3 차 예비검사는 전문가로부터 내용타당도를 검증받고, 단어 발음이 정확하게 녹음된 문항만을 선별하기 위하여 실시되었다.

먼저 1 차 예비검사는 서울 북부지역의 초등학교 $1,2,3$ 학년 아동 73명을 대상으로 실시되었다. 문항에 포함된 자소의 비율을 고려하 여 추려진 120 문항을 30 개씩의 문항으로 나누어 4 개의 검사지를 제 작하였다. 검사는 담임교사들이 전체 학급 아동을 대상으로 실시 하였다. 무의미단어는 학급 담임교사에게도 생소한 단어들이었으 므로 검사의 신뢰도를 위하여 검사단어가 3 번씩 녹음된 녹음파일 을 제공하였다. 검사 결과는 문항반응이론을 응용하여 문항의 난 이도를 추정해 주는 라쉬 이분식 모형(racsh)을 적용하여 분석되었 다. 문항반응이론은(Baker \& Kim, 2004) 피험자 집단의 능력에 따 라 문항의 특성이 다르게 추정되거나 검사의 특성에 따라 피험자의 능력이 다르게 추정되는 고전검사이론의 단점을 극복할 수 있는 방 법으로 알려져 있다. 본 연구에서 개발하고자 하는 검사도구는 어 려운 문항과 쉬운 문항이 적절하게 포함되어야 하므로 기본적으로 $-3.00 \sim+3.00$ 의 난이도를 적절한 난이도의 기준으로 정하였으며

Table 2. Types of items constructing KDSA-NW

\begin{tabular}{|c|c|c|c|c|c|c|c|c|}
\hline Category & Principal vowel & Initial consonant & Final consonant & Aspirated consonant & Tense consonant & Y glide & W glide & Example \\
\hline Type1 & 0 & 0 & 0 & & & & & 즘솝 \\
\hline Type2 & 0 & 0 & 0 & 0 & & & & 립춘 \\
\hline Type3 & 0 & 0 & 0 & & 0 & & & 깡몬 \\
\hline Type4 & 0 & 0 & 0 & & & 0 & & 몰뱐 \\
\hline Type5 & 0 & 0 & 0 & & & & 0 & 궘든 \\
\hline Type6 & 0 & 0 & 0 & 0 & & 0 & & 듈킫 \\
\hline Type7 & & 0 & 0 & 0 & & & 0 & 쉼칙 \\
\hline Type8 & 0 & 0 & 0 & & 0 & 0 & & 멈뼉 \\
\hline Type9 & & 0 & 0 & & 0 & & 0 & 눌짝 \\
\hline
\end{tabular}

KDSA-NW= Korean Developmental Spelling Assessment-Nonword. 
\pm 1.00 까지 허용 범위를 두었다. 다만, 기본모음은 유형 자체가 매 우 쉬운 유형이었기 때문에 기본모음 유형에 한해서만 기본모음의 평균 점수인 -7.06 에서 \pm 1.00 까지 허용범위를 두어 기본모음의 난 이도 선정 기준을 $-8.06 \sim+4.00$ 으로 설정하였다. 이와 같은 난이도 기준에 부합한 단어들로 49 개의 단어가 선별되었다.

2 차 예비검사는 1 차 예비검사 결과 선정된 49 개의 문항 중 적절 한 문항의 난이도와 변별도를 가진 문항들을 선정하기 위하여 실시 되었다. 경기지역에 위치한 한 초등학교의 $1,2,3$ 학년 학생 141 명을 대상으로, 1 차 예비검사와 동일한 방법으로 실시되었다. 문항반응 모형 중 문항의 난이도와 변별도를 분석하는 2-모수 모형을 적용하 여 분석하였다. 문항난이도 기준은 1 차 예비검사와 동일하였으며 문항변별도는 65 이상의 변별도를 적절한 변별도 기준으로 정하였 다(Seong, 2014). 분석 결과 난이도(벙쏩, 슫췰)와 변별도(블쿡, 벙쏩, 돋픔, 봔텅, 슫췰, 쭐뉙) 기준에 부합하지 않은 6개의 단어를 제외하 여 43 개의 단어가 선별되었다.

3 차 예비검사는 검사도구에 포함될 문항을 선정하기 위한 최종 점검 과정이었다. 먼저 선정된 43 개의 단어가 철자능력을 검사하기 에 적절한지 알아보기 위해 교육학과 및 국어국문학과 교수 2 명에 게 단어의 내용타당도에 대한 평가 설문을 실시하였다. 교육학과 교 수에게는 단어가 연구대상에게 적절한 난이도인지, 국어국문학과 교수에게는 음운학적으로 적절한 단어들인지 체크하도록 요청하 였다. 설문 결과 3 개의 문항(뜽뭄, 쇨츱, 쥥썹)이 적절하지 않은 문항 이라고 응답되어 최종문항에서 제외되었다.

또한 무의미단어이면서 자음과 모음이 다소 복잡하게 연결되어 있는 문항은 발음상 구분이 잘 되지 않는 경우도 있기 때문에 단어 를 녹음한 검사자료의 적절성에 대한 최종 점검이 필요했다. 서울소 재 대학에 재학 중인 대학생 및 대학원생 6 명에게 철자검사와 설문 조사를 실시하여 이들이 음소를 정확히 인지하기 어려운 검사문항 이 있는지 확인하였다. 점검 결과 6 명 중 4 명 이상이 틀린 문항과, 녹 음된 파일을 듣고 단어가 무엇인지 정확하게 파악하기 어렵다고 응 답한 단어 4 개(럼솝, 딛퓰, 뻥둅, 괃퉁)를 문항에서 제외하였다.

세 차례의 예비검사를 실시한 결과 총 36 개의 문항이 최종 검사 도구(KDSA-NW)에 포함되기에 적절한 문항으로 추려졌다. 연구 자들은 한정된 문항으로 모든 목표 유형에 대한 철자능력을 측정하 기 위해 문항을 개발하고자 하였고, 이를 위해 36 개 문항 중에서 자 소의 수가 계획한 비율에 부합하도록 균형을 맞추어 30 개의 문항을 최종 검사도구 문항으로 선정하였다.

\section{본검사}

예비검사를 통해 선정된 30 개의 무의미단어들로 구성된 최종 철
자 검사도구(KDSA-NW)가 개발되었다. 초등학교 $1,2,3$ 학년 아동 의 철자능력을 측정하는 데 적합한지 알아보고자 검사도구의 신뢰 도와타당도를 검증하는 본검사를 실시하였다.

\section{연구대상}

KDSA-NW의 내적일관성신뢰도, 반분신뢰도, 구성타당도, 공인 타당도를 확인하기 위해 서울, 경기 지역에 위치한 초등학교 4곳의 $1,2,3$ 학년 학생 총 779 명을 대상으로 본검사를 실시하였다. 초등 학교 4곳 모두에서 학년별로 2-3학급이 참여하였다. 학년별로는 1 학년 235명, 2학년 262명, 3학년 282명이었으며 남학생 404명, 여학 생 375명이었다. 이들에게는 공인타당도 구인을 위해 표준화된 철 자검사도구인 KDSA 음운유형 검사가 실시되었는데 연구 대상 중 109 명이 철자부진 아동인 것으로 드러났다(Yang, Ra, et al., 2016).

KDSA-NW의 내용타당도를 검증하기 위한 설문조사에는 서울, 경기 지역의 초등학교 4 곳의 $1,2,3$ 학년 담임교사들 33 명이 참여하 였다. 그중 현재 맡고 있는 학년이 1학년인 교사는 9명, 2학년인 교 사는 12 명, 3 학년인 교사는 12 명이었다. 1 학년 교사들의 경력은 평 균 16.3년(해당 학년 경력 3.8년), 2학년 교사들의 경력은 평균 15.1 년(해당 학년 경력 2.8 년), 3 학년 교사의 경력은 평균 10.7 년(해당 학 년 경력 2.2년)이었다.

\section{검사도구}

본검사는 본 연구를 통해 개발된 KDSA-NW와 더불어, 공인타 당도 검증을 위하여 표준화된 철자검사도구인 KDSA 중 음운유형 의 검사가 실시되었다. 또한 내용타당도 검증을 위해 타당도 설문 지를 사용하였다.

\section{무의미단어 한글 철자 발달검사(KDSA-NW)}

무의미단어 철자검사인 KDSA-NW는 이전 연구에 기반을 두어 제작되었으며(Yang, 2005, 2014; Yang, Ra, et al., 2016), 세 차례에 걸친 예비검사 결과로 선별된 30 개의 검사문항으로 이루어졌다. 검 사문항은 2 음절 CVC-CVC 형태의 무의미단어로 이루어져 있으며 7개의 철자 목표 유형들을 측정하도록 구성되었다. KDSA-NW가 검사하는 7 개의 철자유형들은 기본모음, 기본초성, 기본종성, 거센 소리초성, 된소리초성, $\mathrm{y}$ 계열모음, $\mathrm{w}$ 계열모음이었다. 각 철자 검사 문항은 3-5개의 목표 유형들을 포함하였다. 예를 들어, ‘근덩'은 기 본모음, 기본초성, 기본종성을 검사하는 문항이었으며, '링솬'은 기 본모음, 기본초성, 기본종성, $\mathrm{w}$ 계열모음을 검사하는 문항이었다. 학생들에게는 철자를 수행할 답안지와 검사문항이 녹음된 녹음 파일이 주어졌다. 검사가 시작되기 전 교사는 학생들이 일부분이라 
도 아는 글자들을 최대한 쓰게끔 격려하였으며, 연습문제를 통해 학생들이 검사방법을 이해하였는지 확인하였다. 검사가 시작되면 단어를 3 회씩 들려주었으며 검사에 소요된 시간은 10 분 내외였다.

\section{한글 철자 발달검사(KDSA)}

한글 철자 발달검사 $(\mathrm{KDSA})$ 는 초등학교 1,2 학년 아동을 대상으 로 표준화된 철자 검사도구이며 현재 표준화되어있는 유일한 단어 철자검사이다. $\mathrm{KDSA}$ 는 초등학교 저학년 수준의 학생들이 익숙한 단어들로 구성되어있으며 철자발달이론에 기초하여 음운유형 검 사지와 형태소유형 검사지 두 개로 구성되어 있다. 본 연구에서는 소리 나는 대로 철자하는 능력을 측정하는 음운유형 검사지를 실 시하여 KDSA-NW검사의 공인타당도를 검증하고자 하였다. $\mathrm{KDSA}$ 음운유형 검사지와 KDSA-NW검사지는 둘 다 한글의 음 운적 철자능력을 검사한다는 점에서 같지만 $\mathrm{KDSA}$ 의 문항은 의미 단어, KDSA-NW의 문항은 무의미단어라는 점에서 다르다. KDSA 음운유형 검사지는 하나의 문항마다 하나의 목표 유형을 측정하도 록 설계되었다. 음운유형에 포함된 목표 유형은 총 5 개로 연음, 기 본초성과 기본모음, 기본종성, 거센/된소리초성, $\mathrm{w} / \mathrm{y}$ 계열모음으로 KDSA-NW와 유사하다. 각 목표 유형에 대한 철자능력은 5 개의 검 사문항으로 측정되며 총 25 문항으로 구성되어 있다. $\mathrm{KDSA}$ 음운 유형 검사의 반분신뢰도는 .98이며, 내용타당도 지수(content validity index: CVI)는 단어와 예문에서 모두 .71-.75이었다.

내용타당도 설문지

KDSA-NW의 내용타당도를 검증하기 위하여 연구자들은 문항 의 적절성을 묻는 설문지를 제작하였다. 각 문항이 목표 철자 유형 을 검사하기에 적합한지 여부에 대해 5 점 척도로 응답하도록 하였 다 $(1=$ 매우 그렇지 않다, $2=$ 그렇지 않다, $3=$ 보통이다, $4=$ 그렇다, $5=$ 매우 그렇다). 예를 들어, ‘근덩'의 경우 기본모음 ' - ㄱ' ', 기본초 성 'ㄱ, ᄃ', 기본종성 'ㄴ, O'을 측정하고자 개발된 단어였으므로 '근덩'이 기본모음 '- - '를 검사하기에 적합한지, 기본초성 ‘ ᄀ. ᄃ' 를 검사하기에 적합한지, 기본종성 'ㄴ, O’를 검사하기에 적합한지 를 목표 유형별로 질문하였다. 이처럼 30개의 단어들이 각각 3-5개 의 목표 유형들을 검사하기에 적절한지 질문한 내용타당도의 설문 문항은 총 135 개였다.

\section{검사방법}

연구자들은 사전에 교사들에게 검사의 목적과 검사의 구성, 검 사 방법과 설문 방법에 대한 자세한 설명을 제공하였으며, 검사 방 법을 숙지하였는지 한 번 더 확인하였다. 연구에 활용된 검사는 집
단검사로 담임교사가 반의 모든 학생을 대상으로 검사를 실시하였 다. 교사는 연습문제를 제시하고 그 수행 결과를 확인하여 아동이 검사 방법을 이해하였는지 확인한 후 검사를 실시하였다. KDSA$\mathrm{NW}$ 검사와 $\mathrm{KDSA}$ 음운유형 검사는 7일 간의 검사 기간 내에 각기 다른 날 실시되었으며 두 개의 철자검사는 각각 10 분 내외로 소요 되었다. 내용타당도 설문지는 철자검사를 실시한 33 명의 교사에게 우편으로 송부되었다.

\section{자료 수집 및 분석}

두 개의 철자검사에 대한 학생의 답안지와 내용타당도 설문지는 담임교사를 통해 우편으로 회수되었으며 연구자들이 채점하였다. KDSA-NW의 채점 방법은 각 단어에 포함된 목표 철자유형들에 대해 개별적으로 정오를 채점하는 방식이었다. 예를 들어, ‘근덩'이 라는 문항에는 기본모음 'ㄱ, ㄱ', 기본초성 'ㄱ, ᄃ', 기본종성 'ㄴ, o'의 목표 유형들이 포함되어 있었다. 각 목표 유형 당 1 점을 부여 하여 기본초성 자소를 모두 올바르게 채점한 경우 1 점, 그렇지 않은 경우 0점으로 기록하였다. 만약 '근덩'을 '믄덩'이라고 철자하였을 경우에는 기본모음 점수는 1 점, 기본초성 점수는 0 점, 기본종성 점 수는 1 점이 기록된다.

KDSA-NW 검사의 적절성을 검증하기 위해 먼저 문항의 난이 도, 변별도를 산출하였고 이어서 문항내적일관성신뢰도와 반분신 뢰도를 통해 신뢰도를 검증하였다. 타당도는 내용타당도와 구성타 당도, 공인타당도로 검증하였다.

\section{연구결과}

\section{학년별 철자성취수준}

KDSA-NW의 유형 점수들을 모두 합산한 총점의 평균과 표준 편차는 Table 3 에 제시되어 있다. 1 학년의 목표 유형들을 합산한 전

Table 3. Descriptive statistics of children's spelling performances

\begin{tabular}{lcccc}
\hline & $\begin{array}{c}\text { 1st grade } \\
(\mathrm{N}=235)\end{array}$ & $\begin{array}{c}\text { 2nd grade } \\
(\mathrm{N}=262)\end{array}$ & $\begin{array}{c}\text { 3rd grade } \\
(\mathrm{N}=282)\end{array}$ & $\begin{array}{c}\text { Total } \\
(\mathrm{N}=779)\end{array}$ \\
\hline Principal vowel & $23.4(4.75)$ & $24.98(2.53)$ & $25.77(3.07)$ & $24.79(3.64)$ \\
Initial consonant & $23.14(4.71)$ & $23.83(3.19)$ & $24.92(3.07)$ & $24.02(3.75)$ \\
Final consonant & $7.93(4.85)$ & $10.74(4.84)$ & $13.93(4.36)$ & $11.05(5.27)$ \\
Aspirated consonant & $7.38(2.12)$ & $7.81(1.58)$ & $8.34(1.61)$ & $7.87(1.81)$ \\
Tense consonant & $7.47(3.56)$ & $8.73(2.56)$ & $9.99(2.36)$ & $8.81(3.01)$ \\
Y glide & $6.51(3.14)$ & $7.75(2.47)$ & $8.28(2.54)$ & $7.57(2.8)$ \\
W glide & $3.93(2.43)$ & $5.27(2.58)$ & $6.44(2.34)$ & $5.29(2.65)$ \\
Total & $79.76(20.83)$ & $89.15(14.08)$ & $97.67(14.18)$ & $89.4(17.96)$ \\
\hline
\end{tabular}

Values are presented as mean (SD). 
체 점수의 평균은 79.76 이었으며, 2 학년의 점수는 89.15 였다. 3 학년 의 경우 97.67 로 학년이 높아질수록 전체 평균 득점이 높아지는 것 으로 나타났다. 영역별 평균 역시 학년이 높아질수록 득점이 높아 지는 것으로 나타났다.

\section{문항의 난이도와 변별도}

문항의 난이도와 변별도는 문항반응이론에 근거하여 분석하였 다. 문항반응이론은 문항의 특성이 피험자의 능력 분포에 의해 영향 을 받지 않고 추정되며, 피험자의 능력 역시 문항들의 특성에 영향을 받지 않고 측정될 수 있음을 가정한다. 문항반응모형에 중 문항의 난 이도와 변별도를 분석하는 2-모수 모형을 사용하여 분석하였다.

문항의 난이도에 대한 절대적인 해석의 기준은 없으나 대체적으 로 -2.0 미만이면 매우 쉬운 문항, -2.00 - 0.50 이면 쉬운 문항, -0.50 $\sim+0.50$ 이면 중간, $+0.50 \sim+2.00$ 이면 어려운 문항, +2.00 이상이면 매우 어렵다고 해석한다(Seong, 2014). 각 유형별로 분석한 문항의 난이도 평균은 기본모음은 -2.48 , 기본초성은 -2.08 , 기본종성은 +0.76 , 거센소리초성은 -1.59 , 된소리초성은 -0.74 , $\mathrm{y}$ 계열모음은 -0.63 , $\mathrm{w}$ 계열모음은 0.00 으로 나타나, 매우 쉬운 난이도부터 어려운 난이 도까지 고루 분포함을 보여주었다.

문항변별도를 살펴보면 0.65 이상이면 변별도가 적절한 문항으로 해석하는 기준에 따라(Seong, 2014), 모든 유형에서 적절한 변별도를 보이는 것으로 나타났다(기본모음 $=+0.89$, 기본초성 $=+0.88$, 기본 종성 $=+1.13$, 거센소리초성 $=+1.24$, 된소리초성 $=+1.60$, $\mathrm{y}$ 계열모음 $=+1.23$, $\mathrm{w}$ 계열모음 $=+1.44)$.

\section{신뢰도}

문항내적일관성신뢰도(internal consistency reliability)

문항내적일관성신뢰도는 Cronbach's $\alpha$ 계수로 분석하였다. 문항 내적일관성신뢰도의 결과는 Table 4 에 제시되어 있다. 전체 문항의 내적일관성을 측정한 크론바흐 알파 값은 .94로 나타났으며 하위

Table 4. Internal consistency reliability of KDSA-NW

\begin{tabular}{lc}
\hline Spelling feature & Cronbach's a \\
\hline Principal vowel & .73 \\
Initial consonant & .73 \\
Final consonant & .83 \\
Aspirated consonant & .61 \\
Tense consonant & .79 \\
Y glide & .73 \\
W glide & .76 \\
Total & .94 \\
\hline
\end{tabular}

KDSA-NW = Korean Developmental Spelling Assessment-Nonword.
철자유형별로는 거센소리초성 유형을 제외한 모든 유형들의 내적 일관성이 .70 이상인 것으로 나타났다. 신뢰도 값이 .70 이상이면 내 절일관성신뢰도가 수립된 것으로 밝혔던 Nunnally (1978)의 기준 에 따라 KDSA-NW의 문항내적일관성신뢰도는 전반적으로 적절 한 것으로 볼수 있다.

\section{반분신뢰도(split-half reliability)}

본 검사도구는 목표 유형이 동일한 문항들끼리 차례로 구성되어 있어 앞에는 목표 유형의 조합이 쉬운 단어들로, 뒤로 갈수록 어려 운 단어들로 구성되어 있다. 따라서 본 연구에서는 짝수 문항과 홀 수 문항으로 반분하는 기우법을 사용하여 반분신뢰도를 산출하였 다. 분석 기준은 문항내적일관성신뢰도와 동일하게 Nunnally (1978) 의 기준을 적용하였으며 Spearman-Brown의 값을 산출하였다.

Table 5에 제시된 바와 같이 전체 문항에 대한 반분신뢰도는 .86 으로 높은 수준이었다. 유형별로 살펴보면, 기본모음은 .74, 기본초 성은 .74, 기본종성은 .84, 된소리초성은 .82, $\mathrm{y}$ 계열모음은 .74, $\mathrm{w}$ 계 열모음은 .77로 모두 신뢰할만한 기준치에 부합하는 것으로 나타 났다. 한편, 거센소리초성의 Spearman-Brown 값은 .63으로 신뢰 할만한 기준에는 미치지 못하였지만 허용할만한 수준인 .60 의 기 준에는 부합하는 것으로 나타났다. 따라서 KDSA-NW 반분신뢰 도는 적절한 것으로 결론지을 수 있다.

\section{타당도}

\section{내용타당도}

검사도구에 포함된 단어들이 해당 목표 유형을 정확하게 측정하 는 지에 대한 내용타당도를 검증하였다. Lawshe (1975)가 제시한 내용타당도비율(content validity ratio, CVR)에 따라 검사문항이 타당한지에 대해서 5 점 척도 $(1=$ 매우 적합하지 않다, $2=$ 적합하지 않다, $3=$ 보통이다, $4=$ 적합하다, $5=$ 매우 적합하다)의 설문지 형태 로 제시하여 문항에 대한 타당도를 검증하였다.

Table 5. Split-half reliability of KDSA-NW

\begin{tabular}{lc}
\hline Spelling feature & Spearman-Brown \\
\hline Principal vowel & .74 \\
Initial consonant & .74 \\
Final consonant & .84 \\
Aspirated consonant & .63 \\
Tense consonant & .82 \\
Y glide & .74 \\
W glide & .77 \\
Total & .86 \\
\hline
\end{tabular}

KDSA-NW= Korean Developmental Spelling Assessment-Nonword. 
Table 6. Model fit of KDSA-NW ( $\mathrm{N}=779)$

\begin{tabular}{cccccccc}
\hline & $\chi^{2}$ & $d f$ & $\chi^{2} / d f$ & $p$-value & RMSEA & SRMR & CFI \\
\hline KDSA-NW & $18,293.17$ & 8,889 & 2.06 & $<.001$ & .03 & .05 & .57
\end{tabular}

KDSA-NW=Korean Developmental Spelling Assessment-Nonword; RMSEA=root mean square error of approximate; $S R M R=$ standardized root mean square residual; $C F I=$ comparative fit index.

전체 문항에 대한 내용타당도비율(CVR)값은 48 로 나타났다. 이 와 같은 결과는 전문가 30 명을 대상으로 내용타당도 검증을 할 경 우 CVR는 33 이상이어야 한다고 제시한 Lawshe (1975)의 기준을 상회한다. 따라서 KDSA-NW의 내용타당도가양호함이 검증되었다.

\section{구성타당도}

측정하고자 하는 구성개념을 검사문항이 제대로 측정하는지 검 증하기 위해 구성타당도를 검증하였다. KDSA-NW는 선행 연구들 의 결과를 토대로 설계되었으므로(Kim \& Yang, 2015; Yang, 2005, 2006, 2009, 2014; Yang \& Lee, 2012; Yang \& Yoon, 2008; Yang, Ra, et al., 2016) 요인분석 중 검사도구를 구성하는 요인과 문항들이 타 당한 모형을 이루고 있는지 확인하는 확인적 요인분석(confirmatory factor analysis, CFA)을 실시하였다.

확인적 요인분석을 실시하는 데 표본의 적절성을 측정하는 Kaiser-Meyer-Olkin (KMO) 지수는 .87이었다. 또한 변인들 간의 상관 이 없음을 검정하는 바틀렛 구형성 검사 결과는 $29,107.54(d f=9,045$, $p<.001)$ 로 유의수준 .001에서 통계적으로 유의미한 것으로 나타 났다. 따라서 수집된 표본이 요인분석을 실시하기에 적합한 것으로 나타났다.

확인적 요인분석을 통해 얻은 모형의 주요 적합도 지수(fit index) 는 Table 6에 제시되어 있다. 본 연구에서는 Kline (2005)이 최근 연 구 경향과 권장 사항을 근거로 필수적이라고 선정한 적합도 지수 들을 확인하였다. Kline (2005)이 제시한 적합도 지수는 카이제곱 $\left(\chi^{2}\right)$, 근사평균오차제곱근(root mean square error of approximate, RMSEA), 표준화 원소간평균차이(standardized root mean square residual, SRMR), 비교부합지수(comparative fit index, CFI) 값이었 다. 먼저 $\chi^{2}$ 은 통계 검증이 가능한 유일한 지수이지만 표본이 클수 록 유의확률이 낮아진다는 단점이 있다. 따라서 표본이 큰 경우 $\chi^{2}$ 을 자유도 $(d f)$ 로 나눈 표준 카이제곱 값(normed chi-square, NC) 으로 적합도를 평하기도 한다. KDSA-NW 는 700명 이상을 대상으 로 검증되어 표본이 큰 편이었다. 따라서 $\chi^{2}$ 으로 적합도를 측정했을 때는 그 값이 $18,293.17$ ( $d f=8,889, p<.001)$ 로 나타나 유의확률이 .05 이상이어야 하는 기준에 부합하지 않았다. 하지만 NC값은 2.06 으로 산출되어 NC값의 기준을 5 이하로 보는 이론에(Salisbury, Pearson, Pearson, \& Miller, 2001) 근거했을 때 적합한 모델이라고
볼수 있다.

표본의 크기에 민감한 $\chi^{2}$ 통계량 외에 표본 크기에 영향을 받지 않 는 적합도 지수인 RMSEA 값도 확인하였다. RMSEA 값은 .04보다 작으면 적합도가 우수하다고 해석하는데 KDSA-NW의 RMSEA 은 .03 로 나타나 높은 모형 적합도를 보였다. SRMR은 표본상관행 렬과 모상관행렬의 차이제곱의 합에 제곱근을 취한 것을 표준화 한 지수로 .05보다 낮으면 우수한 적합도를 보인다고 해석된다. 본 연구에서 분석한 KDSA-NW 모형의 SRMR은 .05로 우수한 모델 이라고 볼수 있었다.

절대적합도 지수인 카이제곱, RMSEA, SRMR에 더하여 연구자 들은 KDSA-NW의 증분적합도 지수인 CFI를 분석하였다. 증분적 합도 지수란 연구자가 개발한 모형이 기초모형(base model)에 비 해 더 나은 적합도를 보이는지를 평가하는 지수이다. CFI는 기초모 형을 영모형(null model)으로 설정하였는데, 영모형은 측정변수들 간에 관계가 없다는 것을 가정한 모형이기 때문에 최악의 모형이라 고 할 수 있다. $\mathrm{CFI}$ 는 90 이상이면 좋은 적합도를 보이는 것으로 간 주하나(Hu \& Bentler, 1999) 본 모형의 CFI는 .57로 기준점에 미치 지 못하는 것으로 나타났다.

\section{공인타당도}

공인타당도 분석을 위해 KDSA-NW 점수와 KDSA의 음운유형 점수 간의 상관관계를 분석하였다. 분석 결과 $\mathrm{KDSA}-\mathrm{NW}$ 점수와 $\mathrm{KDSA}$ 의 음운유형 점수간의 상관계수는 .67로 나타났으며 $(p<.01)$, 이는 선행연구의 기준에 따라 높은 상관을 갖는 것으로 볼 수 있었 다(Seong, 2004). 따라서 KDSA-NW 검사의 공인타당도는 입증되 었다고 할수 있다.

\section{논의 및 결론}

본 연구는 초기 문해력의 중요한 발달과업인 음운적 철자발달을 정확하게 측정할 수 있는 표준화된 철자검사를 개발하는 데 목적 이 있었다. 학급 단위 받아쓰기 검사로 대표되는 기존의 철자검사 들은 의미단어를 철자하도록 지시하고 있다. 이 경우 아동들은 기 억에 의존하여 철자를 하는 경우가 많은데, 기억에 의존한 철자를 하게 되면 아동이 가지고 있는 음운적 철자능력을 정확하게 측정 
하는 데 한계가 있다. 그러나 한글은 표음문자이며 학습의 초기단 계에서 음가대로 표기하는 능력인 음운적 철자능력을 갖추는 것 이 매우 중요하다. 따라서 한글 철자를 본격적으로 학습하는 초등 학교 저학년 아동을 대상으로 어휘력 또는 기억력 변인을 통제하고 아동의 음운적 철자능력을 정확하게 측정할 수 있는 검사도구가 필요하다. 이에 따라 본 연구에서 무의미단어 철자 발달검사도구인 KDSA-NW를 개발하고자 하였다.

KDSA-NW는 이전 연구들을 토대로 철자유형들을 선정하고 목 표 유형들로 구성된 예비문항 단어를 개발하였다(Kim \& Yang, 2015; Yang, 2005, 2006, 2009, 2014; Yang \& Lee, 2012; Yang \& Yoon, 2008; Yang, Ra, et al., 2016). 개발한 검사문항 중 적절한 문 항들을 선정하기 위해 세 차례 예비검사를 실시하였으며 문항의 난이도, 변별도, 내용타당도 등에 기반하여 무의미단어 한글 철자 발달검사(KDSA-NW)를 구성하였다. 최종 개발된 KDSA-NW는 초등학교 저학년 시기에 발달하는 음운적 철자발달에 대해 면밀 히 살펴볼 수 있는 검사도구로 기본모음, 기본초성, 기본종성, 거센 소리초성, 된소리초성, $\mathrm{y}$ 계열모음, $\mathrm{w}$ 계열모음의 7 개 목표 유형들을 검사할 수 있도록 설계되었다. 검사문항은 30 단어로 2음절 CVC$\mathrm{CVC}$ 형태의 무의미단어로 구성되었다

본 연구에서 개발한 무의미단어 한글 철자발달검사(KDSA-NW) 의 신뢰도와 타당도를 검증하기 위해 초등학교 1,2,3학년 아동 779 명을 대상으로 본검사가 실시되었다. 수집된 자료를 토대로 문항의 난이도와 변별도를 산출하여 문항의 특성을 분석하였고, 문항내적 일관성신뢰도, 반분신뢰도를 산출하여 신뢰도를 검증하였다. 또한 내용타당도, 구성타당도, 공인타당도를 산출하여 검사도구의 타당 도를 검증하였다. 본 연구의 결과를 요약하면 다음과 같다.

KDSA-NW의 문항 난이도와 변별도는 적절하였으며 검사도구 의 신뢰도를 검증한 결과, 문항내적일관성신뢰도 계수인 크론바흐 알파 값이 .94로 나타나 높은 수준의 내적일관성을 확인하였다. 하 위 유형별로 살펴보면 기본모음(.73), 기본초성(.73), 기본종성(.83), 거센소리초성(.61), 된소리초성(.79), $\mathrm{y}$ 계열모음(.73), w계열모음(.76) 의 모든 영역에서 적합한 기준치에 부합하는 것으로 나타났다. 또 한 전체 문항의 반분신뢰도 계수는 .86로 산출되었고, 하위 유형별 로도 기본모음(.74), 기본초성(.74), 기본종성(.84), 거센소리초성 (.63), 된소리초성(.82), $\mathrm{y}$ 계열모음.74), $\mathrm{w}$ 계열모음(.77)의 모든 영역 에서 적합한 기준치에 부합하였다. 이와 같은 신뢰도 계수는 $\mathrm{KD}-$ SA-NW가 아동의 철자능력을 측정하는 데 있어서 측정학적으로 일관적 수치와 정보를 제공해줄 수 있음을 말해준다.

KDSA-NW의 타당도 검증은 내용타당도, 구성타당도, 공인타 당도를 확인해봄으로써 이루어졌다. 내용타당도는 적합 기준을 넘
어 내용적으로 타당한 검사임이 확인되었으며 확인적 요인분석의 절대적합도 지수들이 모두 기준에 부합하였다. 절대적합도 지수가 높아 통계적인 접근에 있어서는 본 검사도구가 타당하다고 볼 수 있었으나 증분적합도 지수인 CFI는 적합하지 않은 것으로 밝혀져 이에 대한 추후 연구가 필요하다. 물론 증분적합도 지수가 연구모 형에 대해 절대적인 관점에서 검증 하는 것이 아니라 연구모형이 기 초모형에 비해 더 좋은지에 대한 상대적인 지표를 보여줄 뿐이지만 추후 문항에 대한 수정 또는 제거를 검토해 볼 필요가 있다. 더불어 KDSA-NW 점수와 KDSA 음운유형 점수 간의 상관계수로 증명된 공인타당도는 높은 수준으로 밝혀졌다. 따라서 KDSA-NW가 철 자능력을 측정하는 데 전반적으로 타당한 도구이며 구성타당도에 서 일부 보완해야 할 점이 있는 것으로 결론지을 수 있다.

종합하면 개발된 KDSA-NW는 초등학교 1,2, 3학년 학생들의 음운적 철자능력에 대해 일관적이고 타당한 정보를 제공해줄 수 있다는 것이 본 연구를 통해 검증되었다. 하지만 일부 문항들에 대 해 수정이 필요한 것으로 나타났다. 예를 들어, 문항변별도 결과 일 부 기본모음 문항이 기준치보다 낮았는데 '링손'의 경우 기본모음 'l'의 문항변별도가 0.17 로 나타나 변별도가 없는 문항인 것으로 밝혀졌다. 또한 증분적합도 지수를 조금 더 향상시킬 수 있도록 문 항을 수정 또는 제거하여 검사도구의 타당도를 보강할 필요가 있 다고 판단된다.

본 연구에서 개발한 KDSA-NW는 한글 철자발달 단계에서 초 기에 발달하는 음운적 철자능력을 면밀하게 측정할 수 있다는 점 에서 의의가 있다. 특히 무의미단어로 구성되었기 때문에 자소와 음소의 대응규칙을 알고 적용하는 음운적 철자 단계를 측정하기 에 효과적이라고 할 수 있다. 무의미단어를 철자할 때는 의미전략 이나 시각기억 등 어휘적 접근을 최대한 배제하고 자소-음소 대응 규칙을 적용하여 철자하게 된다. 따라서 무의미단어로 구성된 철 자 검사도구는 음운적 철자발달 단계에 있는 초등학교 저학년 아 동을 중점적으로 아동의 철자능력을 측정하고 철자 문제를 진단 는 데 사용될 수 있다.

진단평가의 중요한 목적 중 하나는 교수를 실시하기 전에 아동의 능력과 특성을 파악하여 수업 목표를 설정하고 교수 방법을 적용 할 수 있도록 적절한 정보를 제공하는 데 있다(Seong, 2014). 현재 학교 현장에서 사용하도록 개발된 진단도구들은 어떤 내용을 어떠 한 목표로 교수해야 할 지에 대한 정보가 제한적이라고 보고되고 있다(Lee, 2015). 본 연구에서 개발한 철자검사는 7개의 철자유형 별로 철자발달 수준에 대한 정보를 제공한다는 점에서 이러한 현 실의 대안적인 도구로 사용될 수 있다. 특히 학습장애 및 학습부진 아동들에게 파닉스 교수법은 매우 효과적임이 여러 연구에서 주장 
되고 있다(Kim, Im, et al., 2009; Kim, Kim, Kim, \& Choi, 2012; Kim, Kim, \& Pyo, 2011; Yang, Ra, et al., 2016). 한글 파닉스는 자 소-음소 대응규칙을 가르치는 교수방법으로 KDSA-NW의 검사 결과가 파닉스 교수를 위해 어떤 목표 유형의 자소들을 학습해야 하는지에 대한 정보를 제시할 수 있을 것이다.

본 연구의 가장 큰 제한점은 본검사 과정에 참여한 학생들의 지 역적 분포에 한계가 있었다는 점이다. 본검사에 참여한 학생들은 서울, 경기권 학생들이었기 때문에 표준화 과정에서 수도권 외에 지방에 거주하고 있는 아동들의 성취 수준을 정확하게 반영하지 못했을 가능성이 있다. 서울, 경기 지역 아동을 선정함에 있어서 지 역과 계층의 분포를 고르게 하려는 노력을 통해 어느 정도 제한점 을 보완할 수 있었을 것이라고 예상되지만, 향후 비수도권 지역의 아동들도 포함시켜 개정한다면 좀 더 타당하고 신뢰할 수 있는 검 사도구가 될 수 있을 것이라 생각된다.

\section{REFERENCES}

Bae, J. C. (2003). Korean pronunciation. Seoul: Samkyungmunhwasa.

Baker, F. B., \& Kim, S. H. (2004). Item response theory: parameter estimation techniques (2nd ed.). Boca Raton, FL: CRC Press.

Bishop, D. V. M., \& Robson, J. (1989). Accurate non-word spelling despite congenital inability to speak: phoneme-grapheme conversion does not require subvocal articulation. British Journal of Psychology, 80, 1-13.

Bruck, M. (1993). Component spelling skills of college students with childhood diagnoses of dyslexia. Learning Disability Quarterly, 16, 171-184.

Choi, Y. J., Kim, Y. T., Yun, H. R., \& Sung, J. E. (2011). Spelling ability of the final consonants in children with reading disabilities. Korean Journal of Communication Disorders, 16, 154-170.

Deacon, S. H., Parrila, R., \& Kirby, J. R. (2006). Processing of derived forms in high-functioning dyslexics. Annals of Dyslexia, 56, 103-128.

Ellis, A. W. (1982). Spelling and writing. In A. W. Ellis (Ed.), Normality and pathology in cognitive functions (pp. 113-143). New York, NY: Academic Press.

Graham, S., Berninger, V. W., Abbott, R. D., Abbott, S. P., \& Whitaker, D. (1997). Role of mechanics in composing of elementary school students: a new methodological approach. Journal of Educational Psychology, 89, 170-182.

Henderson, L., \& Chard, J. (1980). The reader's implicit knowledge of orthographic structure. In U. Frith (Ed.), Cognitive processes in spelling (pp. 85116). London: Academic Press.

Hu, L. T., \& Bentler, P. M. (1999). Cutoff criteria for fit indexes in covariance structure analysis: conventional criteria versus new alternatives. Structural Equation Modeling: A Multidisciplinary Journal, 6, 1-55.

Jung, H. L., Kim, B. B., Yang, M. W., \& Lee, A. J. (2016). Preventing dyslexia in multicultural children: effects of phonics instruction for kindergarten children with multicultural backgrounds. Journal of Special Education: Theory and Practice, 17, 297-321.

Kang, H., \& Simpson, G. B. (1996). Development of semantic and phonological priming in a shallow orthography. Developmental Psychology, 32, 860866.

Kim, A. W., \& Kim, U. J. (2013). The effect of phonological-based spelling instruction on spelling of students with writing disabilities. Korea Journal of Learning Disabilities, 10, 51-72.

Kim, A. W., Im, H. K., \& Park, S. H. (2009). Word recognition skills of elementary students in Korea: focusing on word recognition accuracy, word recognition fluency, and error patterns. Korean Journal of Special Education, 44, 157-184.

Kim, A. W., Kim, U. J., \& Pyo, S. R. (2011). The effect of scripted, synthetic phonics instruction program on word identification of children with reading disabilities. Journal of Special Education: Theory and Practice, 12, 613638.

Kim, A. W., Kim, U. J., Kim, J. K., \& Choi, S. S. (2012). Learning disabilities: theory and practice. Seoul: Hakjisa.

Kim, B. B., \& Yang, M. (2015). Articulatory information for spelling strategies. Communication Sciences \& Disorders, 20, 400-412.

Kline, R. B. (2005). Principles and practice of structural equation modeling (2nd ed.). New York, NY: Guilford Press

Landerl, K., Wimmer, H., \& Frith, U. (1997). The impact of orthographic consistency on dyslexia: a German-English comparison. Cognition, 63, 315-334.

Lawshe, C. H. (1975). A quantitative approach to content validity. Personnel Psychology, 28, 563-575.

Lee, D. S. (2015). The characteristics and future direction of government-funded programs for enhancing basic academic abilities of low achieving students. Korea Journal of Learning Disabilities, 12, 101-132.

Lee, H. Y. (1996). Korean phonetics. Seoul: Taehaksa.

Lee, J. H. (2003). A phonological survey on the h-final stem in Korean. Korean Language and Literature, 133, 167-195.

Lee, K. H., \& Jeon, J. R. (2007). A survey on the instruction status and teacher's view of beginning literacy for Korean textbook development. Journal of Learner-Centered Curriculum and Instruction, 7, 277-308. 
Lee, M. K. (1999). /h/ and aspiration in Korean. Journal of Linguistics Science, 16, 383-402.

Lee, S. O. (1994). The phonological rule of a Korean. Proceedings of the Korean Society of Phonetic Sciences and Speech Technology Conference, Seoul, Korea.

Lerner, J. W. (2000). Learning disabilities: theories, diagnosis, and teaching strategies (8th ed.). Boston, MA: Houghton Mifflin Company.

Marsh, G., Friedman, M., Welch, V., \& Desberg, P. (1980). The development of strategies in spelling. In U. Frith (Ed.), Cognitive processes in spelling (pp. 339-353). London: Academic Press.

National Institute of Korean Language. (2005). The modern Korean word frequency II. Seoul: Author.

Newcombe, F., \& Marshall, J. C. (1980). Transcoding and lexical stabilization in deep dyslexia. In M. Coltheart et al. (Eds), Deep dyslexia (pp. 176-188). London: Routledge and Kegan Paul.

Nunnally, J. C. (1978). Psychometric theory (2nd ed.). New York, NY: McGrawHill.

Pae, S., Kim, M., Yoon, H. J., \& Jang, S. (2015). Korean Language Based Reading Assessment (KOLRA). Seoul: Hakjisa.

Salisbury, W. D., Pearson, R. A., Pearson, A. W., \& Miller, D. W. (2001). Perceived security and World Wide Web purchase intention. Industrial Management \& Data Systems, 101, 165-177.

Seong, T. J. (2004). Theory and practice for item construction and item analysis (2nd ed.). Seoul: Hakjisa.

Seong, T. J. (2014). Modern educational evaluation. Seoul: Hakjisa.

Stage, S. A., \& Wagner, R. K. (1992). Development of young children's pho- nological and orthographic knowledge as revealed by their spellings. Developmental Psychology, 28, 287-296.

Wurm, L. H., \& Samuel, A. G. (1997). Lexical inhibition and attentional allocation during speech perception: evidence from phoneme monitoring. Journal of Memory and Language, 36, 165-187.

Yang, M. (2005). Development of orthographic knowledge among Korean children in grade 1 to 6 (Doctoral dissertation). University of Virginia, Charlottesville, VA.

Yang, M. (2009). Spelling development of kindergarten students: a one year longitudinal study. Korean Journal of Communication Disorders, 14, 14-33. Yang, M. (2014). Children's spelling of phonological and morphological features in primary grades. Communication Sciences \& Disorders, 19, 120-131.

Yang, M., \& Yoon, B. E. (2008). Early spelling development of Chinese-native Korean learners. Journal of Korean Education, 35, 107-123.

Yang, M. (2006). A review of theory and research about cross-linguistic spelling development. Korean Journal of Special Education, 41, 163-186.

Yang, M., \& Lee, A. J. (2012). An analysis of the word selection criteria for teaching and testing students with learning difficulties. Special Education Research, 11, 149-166.

Yang, M., Kim, B. B., \& Lee, A. J. (2016). Effects of phonics-based spelling instruction on LD students' writing skills. Korean Writing Association, 29, 241-274.

Yang, M., Ra, J. M., Lee, A. J., \& Kim, B. B. (2016). Development and reliability of Korean developmental spelling assessment (KDSA). Korean Journal of Developmental Psychology, 29, 195-214. 


\section{국문초록}

\section{기초 한글 철자능력 측정을 위한 무의미단어 한글 철자 발달검사도구(KDSA-NW) 개발연구 김보배 · 양민화 \\ 국민대학교 교육학과}

배경 및 목적: 본 연구는 초기 철자발달인 음운적 발달에 대한 아동의 철자능력을 정확하게 측정하고, 철자 문제를 진단할 수 있는 무 의미단어 철자 검사도구를(KDSA-NW) 개발하는 데 목적이 있다. 방법: 문헌분석을 통해 선정된 음운적 7개의 철자유형을 포함한 단 어들로 예비문항을 개발한 후 세 차례 예비검사를 실시하여 검사문항을 선별하였다. KDSA-NW가 검사하는 7개의 음운적 철자유형 들은 기본모음, 기본초성, 기본종성, 거센소리초성, 된소리초성, $\mathrm{y}$ 계열모음, $\mathrm{w}$ 계열모음이었다. 검사문항은 7 개의 철자유형이 포함된 30 개의 2음절 CVC-CVC 단어로써 한국어에 존재하는 무의미단어들이었다. KDSA-NW는 초등학교 1, 2,3학년 779명의 학생을 대상으 로 표준화되었으며 신뢰도 추정을 위해 문항내적일관성신뢰도와 반분신뢰도를 분석하였다. 타당도 검증을 위해서는 내용타당도, 구성 타당도, 공인타당도를 검증하였다. 결과: 문항내적일관성신뢰도 계수인 크론바흐 알파 값과 반분신뢰도 계수가 모두 높게 나타나 KDSA-NW는 신뢰도가 높은 검사임이 검증되었다. 내용타당도 결과는 검사 단어들이 목표한 철자유형들을 측정하기에 적절함을 보여주 었다. 구성타당도는 절대 적합도 지수(normed chi-square, RMSEA, SRMR)들이 양호하게 나타났다. KDSA 음운유형 철자검사와 KDSA-NW의 점수를 비교해본 결과 높은 상관관계가 있는 것으로 확인되어 공인타당도 역시 높은 수준임이 밝혀졌다. 논의 및 결론: KDSA-NW는 신뢰도와 타당도가 높은 검사도구로써 한글 학습자의 파닉스 교수에 대한 요구를 보다 정확하게 진단할 수 있을 것으로 기대된다.

핵심어: 철자검사, 철자발달, 검사개발, 무의미단어, 음운적 철자

이 논문은 제 1 저자의 석사학위논문을 수정·보완한 것임.

이 연구는 2016년도 산업통상자원부 및 산업기술평가관리원(KEIT) 연구비 지원에 의한 연구임(No. 10065156).

\section{참고문헌}

국립국어원(2005). 현대 국어 사용 빈도 조사2. 서울: 국립국어원.

김보배, 양민화(2015). 일반아동과 철자부진아동의 철자전략 비교. 언어청각장애연구, 20,400-412.

김애화, 김의정(2013). 음운처리 중심 철자 교수가 쓰기장애 학생의 철자에 미치는 효과. 학습장애연구, 10, 51-72.

김애화, 김의정, 김자경, 최승숙(2012). 학습장애: 이론과 실제. 서울: 학지사.

김애화, 김의정, 표소래(2011). 스크립트화된 합성 파닉스 교수가 읽기장애학생의 한글 단어인지에 미치는 효과. 특수교육저널: 이론과 실천, 12, 613-

638.

김애화, 임화경, 박성희(2009). 초등학생의 단어인지 특성연구. 특수교육학연구, 44, 157-184.

배소영, 김미배, 윤효진, 장승민(2015). 한국어 읽기 검사. 서울: 학지사심리검사연구소.

배주채(2003). 한국어의 발음. 서울: 삼경문화사

성태제(2004). 문항제작 및 분석의 이론과 실제(2판). 서울: 학지사.

성태제(2014). 현대교육평가(4판). 서울: 학지사.

양민화(2006). 문자발달과정을 설명하는 범언어적인 이론과 문자간 철자발달의 비교연구 Review. 특수교육학연구, 41, 163-186.

양민화(2009). 유치원 아동의 철자발달 단기종단연구. 언어청각장애연구, 14, 14-33.

양민화(2014). 음운론적 유형과 형태론적 유형의 초기 철자발달. 언어청각장애연구, 19, 120-131.

양민화, 김보배, 이애진(2016). 파닉스 기반 철자교수가 작문능력에 미치는 영향-학습장애 학생들을 대상으로. 작문연구, 29, 241-274. 
양민화, 나종민, 이애진, 김보배(2016). 한글 철자 발달검사(Korean Developmental Spelling Assessment: KDSA)의 개발과 신뢰도 연구. 한국심리학 회지: 발달, 29, 195-214.

양민화, 윤보은(2008). 중국인 한국어 학습자의 철자능력 분석연구. 한국교육, $35,108-123$.

양민화, 이애진(2012). 학습부진 학생의 철자검사 및 교수를 위한 단어선정의 언어학적 기준분석. 특수교육, 11, 149-166.

이경화, 전제응(2007). 국어교과서 개발을 위한 기초문식성 지도 실태와 인식 조사. 학습자중심교과교육연구, 7, 277-308.

이대식(2015). 학습부진학생의 기초학력 향상을 위한 정부 지원 사업의 특징과 발전 방향. 학습장애연구, 12, 101-132.

이문규(1999). 음소'ㅎ'과 유기음화. 언어과학연구, 16, 383-402.

이상억(1994, 2). 국어의 음운규칙. 대한음성학회 학술대회 자료집, 서울.

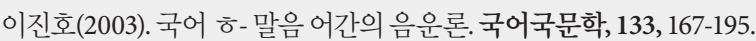

이호영(1996). 국어음성학. 서울: 학지사.

정혜림, 김보배, 양민화, 이애진(2016). 다문화가정 난독증 위기 아동을 위한 예방적 접근: 한글파닉스 교수의 효과성 탐색. 특수교육 저널: 이론과 실 천, 17, 297-321.

최윤정, 김영태, 윤혜련, 성지은(2011). 낱말 친숙도 및 음운규칙 적용 유무에 따른 학령기 읽기장애 아동의 받침철자 인식 및 쓰기 특성. 언어청각장 애연구, 16, 154-170. 